\title{
CBFB/MYH11 Fusion Gene
}

National Cancer Institute

\section{Source}

National Cancer Institute. CBFB/MYH11 Fusion Gene. NCI Thesaurus. Code C101051.

A fusion gene that results from a chromosomal inversion inv(16)(p13q22) which fuses the 5' portion of the CBFB gene with the 3' part of the MYH11 gene. This rearrang ement is associated with acute myeloid leukemia and myelodysplastic syndrome. 